DOI: https://doi.org/10.31933/dijdbm.v2i3

Received: 28 January 2021, Revised: 18 March 2021, Publish: 18 April 2021

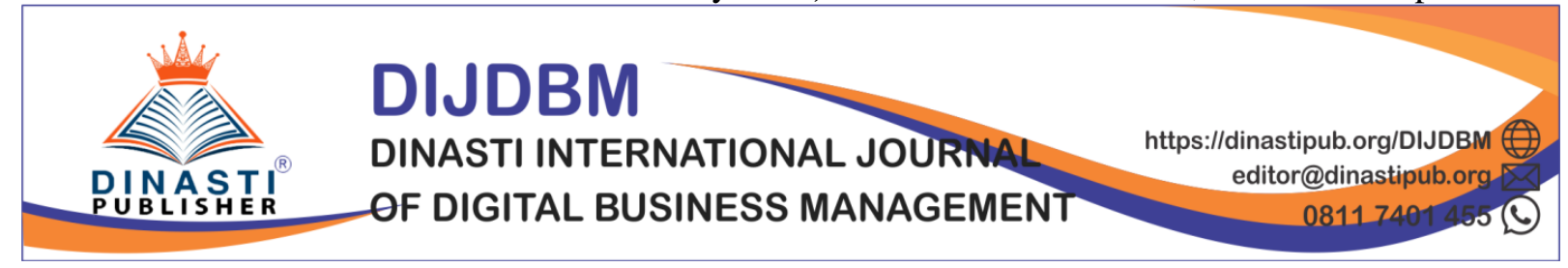

\title{
THE ROLE OF BRAND IMAGE IN MEDIATING THE EFFECT OF PRODUCT QUALITY, SERVICE AND PRICE ON PURCHASE INTEREST
}

\author{
Tri Ajeng Melati ${ }^{1}$, Didik J. Rachbini ${ }^{2}$, Endi Rekarti ${ }^{3}$ \\ ${ }^{1)}$ Mercu Buana University, Jakarta, Indonesia, ajengmelati@gmail.com \\ ${ }^{2)}$ Mercu Buana University, Jakarta, Indonesia
}

\begin{abstract}
The purpose of this study was to analyze the effect of product quality, service and price in influencing purchase intention, as well as to determine the role of brand image mediating the effect of product quality, service and price on purchase interest in the Daihatsu Xenia brand in South Tangerang. The population in this study are people in South Tangerang city who are involved in the process of searching for and purchasing lmpv vehicles. The sample used in this study were 190 respondents. The sampling method was done by using purposive sampling method. This study uses SEM data analysis techniques and data processing using Partial Least Square (PLS). The results of this study indicate that product quality is proven to have a positive and significant effect on brand image, service quality is proven to have a positive and significant effect on brand image, price is proven to have a positive and significant effect on brand image, product quality is not proven to have a positive and significant effect on brand image. Purchase interest, service quality is proven to have a positive but insignificant influence on purchase intention, price is proven to have a positive and significant effect on purchase intention, brand image is proven to have a significant effect on purchase interest. Then in this study it is also proven that brand image fully mediates the relationship of product quality to purchase intention, brand image does not mediate the relationship of service quality to purchase intention, brand image partially mediates the relationship between price and purchase intention.
\end{abstract}

Keywords: Product Quality, Service Quality, Price, Brand Image, Purchase Interest.

\section{INTRODUCTION}

The growing development of the automotive industry has led to the rapid growth of the four-wheeled vehicle (car) industry in Indonesia. The increasing mobility of the people requires them to own private vehicles, therefore automotive companies offer various types of car variants with various categories according to consumer needs. In Indonesia, companies engaged in the automotive sector are dominated by various foreign automotive product manufacturers, such as the Honda brand, Toyota Daihatsu, Suzuki, Nissan, Mazda from Japan, Chevrolet, Ford from America, and several car brands from other countries.

The sales volume of the automotive industry in Indonesia itself has developed from 2015 to 2018. The development of the automotive industry shows a positive direction, following sales volume data from 2015-2018 is presented in Table 1 below: 
Table 1 The Sales Volume of the Automotive Industry in Indonesia in 2015-2018

\begin{tabular}{cc}
\hline Year & Sales volume \\
\hline 2015 & $1,013,518$ unit \\
2016 & $1,062,694$ unit \\
2017 & $1,077,364$ unit \\
2018 & $1,151,308$ unit \\
\hline \multicolumn{2}{c}{ Source: GAIKINDO }
\end{tabular}

Based on Table 1, the sales volume of the automotive industry in Indonesia from 2015 to 2018 continues to experience a significant increase of $13.60 \%$, this is evidence that the automotive industry in Indonesia is very potential and should be taken into account. Cars have become a necessity that cannot be separated from human life. The high demand for means of transportation that continues to increase has made the car industry develop quite rapidly. Until now, there are domestic companies competing with each other to control market share. Here are a number of companies that dominate the car sales market share as follows:

Table 2 Market Share of Car Sales by Brand in 2015-2019

\begin{tabular}{|c|c|c|c|c|c|c|}
\hline No & Brand & 2015 & 2016 & 2017 & 2018 & 2019 \\
\hline 1 & Toyota & $31.80 \%$ & $35.90 \%$ & $34.50 \%$ & $30.60 \%$ & $32.40 \%$ \\
\hline 2 & Daihatsu & $16.60 \%$ & $17.80 \%$ & $17.30 \%$ & $17.60 \%$ & $17.70 \%$ \\
\hline 3 & Honda & $15.70 \%$ & $18.80 \%$ & $17.30 \%$ & $14.10 \%$ & $13.20 \%$ \\
\hline 4 & Suzuki & $12.00 \%$ & $8.70 \%$ & $10.40 \%$ & $10.30 \%$ & $9.40 \%$ \\
\hline 5 & Wuling & $0.0 \%$ & $0.0 \%$ & $0.5 \%$ & $1.5 \%$ & $1.9 \%$ \\
\hline 6 & Mazda & $0.9 \%$ & $0.5 \%$ & $0.4 \%$ & $0.5 \%$ & $0.5 \%$ \\
\hline
\end{tabular}

\section{Source: GAIKINDO}

Based on table 2, it shows that Toyota brand cars rank first in car sales in Indonesia during 2015-2019, the Toyota brand can control the market share of up to 35\%, this shows that consumer purchase interest in Toyota brand cars is higher than other car brands. in Indonesia. Toyota Astra Motor as the sole producer of Toyota cars occupies the first position in the national car sales table, and remains the market leader every year compared to its competitors. The very competitive competition has made some of these car manufacturers carry out various strategies, one of which is by issuing various product variants in order to continue to compete. From table 2 there is also a difference in the level of sales between Toyota and Daihatsu, where both are Japanese car brands, but consumer purchase interest in Daihatsu brand cars is lower than that of Toyota car brands.

Today's consumers tend to find and choose products not only from the quality and features of the product. Technological developments are increasingly rapid day after day, making the products on the market almost no difference, so that all marketers offer products with the same features and quality even at almost the same price, therefore the brand image becomes an added value for the company to sell. to consumers.

A good brand image will generate emotional values for consumers, therefore companies need to improve their brand image. This emotional value will trigger a positive perception of a product. According to Maunaza (2012), through a good brand image emotionally will also form satisfaction in the individual which results in an impression of quality in a brand which ultimately creates repeat purchases.

Business competition is so tight that companies must be able to meet consumer needs and compete in marketing their products. In Indonesia which is very densely populated, many families choose cars as their main means of transportation, especially cars in the Low MPV segment. MPV which stands for Multi-Purpose Vehicle is a type of car that can be used for 
many purposes, with carrying capacity or passenger capacity being the main thing that is highlighted. MPV car is perfect for those of you who need a car with a large passenger capacity, with a carrying capacity of around seven passengers or even more.

MPV cars are further divided into four classes, namely Low MPV, Medium MPV, Compact MPV and Luxury MPV. Here is the sales data for the MPV Car Category in Indonesia for the 2015-2019 period, presented in Figure 1.1 below:

Figure 1. Sales of MPV Car Categories in Indonesia in 2015-2019



\section{Source: GAIKINDO}

The most preferred categories according to sales data in Figure 1.1 are the Low Multi Purpose Vehicle (LMPV) segment with 77\%, 19\% Medium MPV, 3\% Compact MPV, and $1 \%$ Luxury MPV. From this category, the Low Purpose Multi Vehicle car achieved the best sales figures in 2015 of 249,790 units.

Sales of Daihatsu Xenia car products at PT. Astra International Daihatsu in South Tangerang has decreased. The highest sales of Daihatsu Xenia cars were in the Bintaro branch, followed by Ciledug, Alam Sutra and Pamulang. A significant decline in several of the branches above occurred in the 2017-2018 period. In the Bintaro branch there was a decrease of $15.54 \%$, in the Ciputat branch there was a decrease of $19.75 \%$, in the Alma Sutra branch it was $14.17 \%$ and in the Pamulang branch it decreased by $14.57 \%$.

Daihatsu Xenia still holds the title of the best-selling car in the Daihatsu brand for the MPV segment. In product quality, according to Kotler and Amstrong (2008), if marketers pay attention to quality, even reinforced by advertising and fair prices, consumers will not think long about making purchases of products.

This research will analyze several factors that influence consumer purchase interest in searching for, choosing a Daihatsu Xenia car. The interest in choosing this brand is because this MPV car derived from the Toyota Avanza, which is even produced in one manufacturer and priced at a lower price, turns out that sales are still far below the Avanza, namely the Daihatsu Xenia. The Toyota Avanza and Daihatsu Xenia have a special position in the Indonesian automotive industry in the low MPV segment.

The relationship between product quality and purchase intention is explained by the journal Mohamad Yusuf Farhan, and Mustafa (2015) showing the results of research that product quality has a positive and significant effect on purchase intention. A product is said 
to be of quality if it is useful to satisfy consumer wants and needs. If the quality of the product is good, consumers tend to repurchase a product. Product quality is the ability of a product to demonstrate its function, this includes overall durability, reliability, accuracy, ease of operation, and product repair, as well as other product attributes (Kotler \& Amstrong 2012). So that quality has a very important meaning in consumer purchase interest.

Apart from product quality, price is also an important consideration in a person's decision to buy a product. Some consumers even identify price with value. When a product requires consumers to spend more than the benefits received, what happens is that the product has a negative value. Consumers may perceive it as a bad value and then reduce consumption of the product. Low prices are one of the causes of perceived quality to be affected.

Service quality is a very important role because in marketing service products the interaction between producers and consumers occurs directly. With good service quality it can also provide a positive image for the company. Rusydi (2017) "service quality is the level of excellence expected and control over that level of excellence is to meet consumers. Service quality in this definition explains that what is highly valued by consumers is judged by how the company provides the best service to its customers, because with this service a consumer can assess and provide a satisfaction to stay afloat or look for a better one.

The author has conducted pre-research by asking several open-ended questions, one of the main reasons for using open-ended questions is to get answers that are deep, meaningful, and full of consideration. Asking open-ended questions invites people to open up, because it shows that we as researchers are interested in what respondents think. Open questions about "What do you think about the Daihatsu Xenia?" submitted to 30 respondents who started in the search process, and who are currently involved in the process of purchasing a Daihatsu Xenia car domiciled in South Tangerang, the following data were obtained.

The results of the pre-research show that some cheap, affordable and wide-range variable answers have a dominant number as a factor in someone having an interest in buying as many as 30 respondents. Next 27 respondents variable after sales service, reliable. Then 26 respondents when thinking about the Daihatsu Brand that sparked the good image of the dihatsu itself, and Daihatsu cars were considered economical by 25 respondents. As many as 20 respondents said that the service is good and Daihatsu is not easily damaged so that it has a long economic life, selected by 21 respondents. In addition, 19 respondents liked Daihatsu because CS services were easy to contact and friendly, making it easier for consumers to request services. A total of 15 respondents chose Daihatsu because they thought the Daihatsu Xenia car price could compete with other MPV car products.

From a number of answers obtained, the authors classified into four variables. Economical, reliable and long economic life describes part of the quality of the product. Then service, friendly CS service, wide company network, and after-sales service are part of service quality. Cheap, competitive and affordable are part of the price. Popular is part of the brand image.

In previous research conducted by Ratih (2017) "The Role of Brand Image Mediates Product Quality and Prices with Purchase Intention for Apple Smartphone Products in Denpasar City". The results of this study indicate that all hypotheses are accepted. Product quality has a positive and significant effect on brand image, price has a positive and significant effect on brand image, brand image has a positive and significant effect on purchase intention, product quality has a positive and significant effect on purchase intention, 
price has a positive and significant effect on purchase intention, brand image has a positive and significant effect on mediating product quality with purchase intention, brand image has a positive and significant effect on mediating price and purchase intention.

Judging from the pre-survey results, 30 respondents shared their opinions regarding Daihatsu. The author summarizes, the Daihatsu Brand is synonymous with factors, namely economical products, low prices, competitive, affordable, popular and good service. These three dominant variables are able to describe how the Daihatsu brand is, so that these factors encourage one's purchase interest in buying, in this case the Daihatsu Xenia. But the question is why with a brand image that is synonymous with qualified products, low prices, and good, popular service, in fact the Daihatsu Xenia brand is still less competitive with other LMPV brands. Even data in the field shows a decline in sales of Daihatsu Xenia in Indonesia. In this case the author will focus on research at PT. Astra International Daihatsu Xenia in South Tangerang.

\section{LITERATURE REVIEW \\ Brand Image}

Brand image is the customer's understanding of the brand as a whole. Customer trust in a particular brand and how customers perceive a brand. A positive brand image will make customers like a product with the relevant brand in the future, while for producers a good brand image will hinder competitors' marketing activities. Kotler and Armstrong (2013) suggest the definition of brand image "The set of belief held about a particular brand is known as brand image". Which means a set of beliefs about a brand is called a brand image. Kotler and Keller (2012) define brand image as "Preception and beliefs held by consumers. As reflected in the associations held in consumers memory ". as a set of perceptions and beliefs that customers have on a brand which is reflected through the associations that exist in the customer's memory.

According to David Aaker and A. L. Biel (2009), brand image can be seen from:

\section{The image maker (Corporate Image)}

Namely, a set of associations that consumers perceive to companies that make goods or services. For companies, the benefits of a brand are:

a. Brand makes it easy for sellers to process orders and trace problems that arise.

b. Brand provides legal protection for the features or characteristics of the product.

c. Brands make it possible to attract a loyal and profitable group of buyers.

d. Brands help sellers to segment the market.

2. User or consumer image (user or customer image)

a. Brands can tell buyers something about quality.

b. Brands help attract buyers' attention to new products that might benefit the brand.

\section{Product image}

It is a set of associations that consumers perceive to a good or service, such as the following:

a. Genuine or fake product quality.

b. Good quality.

c. Attractive design.

d. Beneficial for consumers. 


\section{Product Quality}

According to Kotler and Keller (2012) product quality is the ability of a product to perform various functions including durability, reliability, accuracy and ease of use. Kotler and Armstrong (2016) Product quality is a characteristic of a product or service that survives its ability to meet stated or implied customer needs. namely:

According to Kotler (2016: 203) product quality can be entered into five dimensions,

1. Performance (Performance) is the most basic dimension and is related to the main function of a product. Consumers will be disappointed if their expectations of this dimension are not fulfilled.

2. Reliability (Reliability) matters relating to profitability or the possibility of an item successfully performing its function every time it is used within a certain period of time.

3. Features (product characteristics) can be said to be a secondary aspect because the development of these features is almost unlimited in line with technological developments, so the features are the target of producers to innovate in order to satisfy customers.

4. Durability is the fourth dimension of product quality which shows a measurement of the product cycle, both technically and over time. Products are called durable if they last after repeated use or have been used for a long time.

5. Design (Design) is a unique dimension and offers many emotional aspects in influencing customer satisfaction.

\section{Price}

According to Kotler and Armstrong (2014) Price is the amount of money exchanged for a product or service. 16 Furthermore, price is the sum of all the value that consumers exchange for the amount of benefit by owning or using a good and service. According to Ferdinand (2013) price is one of the important variables in marketing, where prices can influence consumers in making decisions to buy a product for various reasons. The economic reason will show that the price is low or the price is too competitive is one of the important triggers to improve marketing performance. According to Schiffman and Kanuk (2013) Price is a major factor that can influence a buyer's choice, price plays a role in determining consumer purchases, for that before setting a price, companies should look at some references to the price of a product that is considered high enough in terms of price. sales. namely:

According to Stanton (2013), there are four indicators that characterize prices,

1. Price affordability, where consumers can still reach the price set by the producer.

2. The suitability of price with product quality is a match between the value of a product and the price to be paid.

3. Price competitiveness, namely the power to compete with other products.

4. Price compatibility with benefits, where what kind of benefits are provided in accordance with the price set. 


\section{Service Quality}

According to Rusydi (2017: 39) "service quality is the level of excellence expected and control over that level of excellence is to meet consumers. Service quality in this definition explains that what is highly valued by consumers is judged by how the company provides the best service to its customers, because with this service a consumer can assess and provide a satisfaction to stay afloat or look for a better one.

According to Parasuraman, Zeithaml and Berry (2016) the dimensions of service quality consist of:

1. Tangible (Physical Evidence), with respect to the attractiveness of the physical facilities, equipment and materials used by the company, as well as the appearance of employees.

2. Emphaty (Empathy), means that the company understands the problems of its customers and acts in the interests of customers, as well as giving personal attention to customers and having comfortable operating hours.

3. Responsiveness, relating to the willingness and ability of employees to help customers and respond to their requests, as well as informing when services will be provided and then providing services quickly.

4. Reliability (Reliability), relating to the company's ability to provide accurate service from the first time without making any mistakes and delivering services according to the agreed time.

5. Assurance, ie the behavior of employees is able to foster customer trust in the company and the company can create a sense of security for its customers.

\section{Purchase interest}

According to Kotler and Armstrong (2012) purchase interest is something that arises after receiving stimulation from the product they see, then the desire to buy and own it arises. According to Ferdinand (2013), an indicator of a consumer's purchase interest is as follows, namely:

1. Transactional interest, which is a person's tendency to buy products. This means that consumers already have an interest in making purchases on the desired product.

2. Referential interest, namely the tendency of someone to refer products to others. This means that consumers who already have purchase interest will suggest to others to make purchases on the same product.

3. Preferential interests, namely interests that describe the behavior of someone who has a primary preference for the product. This preference can only be changed if something happens with the preference product.

4. Exploratory interest, this interest describes the behavior of a person who is always looking for information about the product he is interested in and looking for information to support the positive properties of the product.

\section{RESEARCH METHODS}

The research was conducted with a quantitative descriptive approach and the type of research was case studies supported by a survey method.

In this study, the population used is the people in South Tangerang City who are involved in the process of searching for and purchasing LMPV vehicles, the number of which is not known with certainty. In this study, the sampling technique used was nonprobability sampling with purposive sampling technique, according to Sugiyono (2016: 85) Purposive 
sampling is a technique of sampling data sources with certain considerations. The consideration in taking the sample in this study is a person who is searching for an LMPV car, who is involved in the process of searching for and purchasing a car vehicle, a community who lives in South Tangerang and looking for a car at the South Tangerang outlet. Researchers also used snowball sampling techniques in determining South Tangerang as the object of research. The implementation procedure is by visiting each showroom in several regions and conveying the purpose of the research by presenting the research questionnaire. After that, research permits were obtained from several areas that had been contacted and visited in the South Tangerang area showroom.

According to Josep F Hair (2010), the ideal and representative respondent size depends on the sum of all indicators in the variable multiplied by 5-10. In this study, there were 38 question items, thus the respondents for this study were 190 respondents. This number is considered sufficient to represent the population to be studied.

Descriptive analysis is used to describe statistical data such as; minimum, maximum, mean, sum, std deviation, variance, range, and others.

Testing the research hypothesis was carried out by using the Structural Equation Model (SEM) approach based on Partial Least Square (PLS). Latan and Ghozali (2012) stated that PLS is an alternative approach that shifts from a covariance-based SEM approach to one based on variance. Covariance-based SEM generally tests causality or theory while PLS is more of a predictive model. In accordance with the formulated hypothesis, in this study the statistical data analysis was measured using the SmartPLS software expansion of the measurement model (outer model), the model structure (inner model) and hypothesis testing.

The test steps that will be carried out are measurement evaluation, Structural Model Testing or Hypothesis Testing (Inner Model), Research Hypothesis Testing with Mediating Variables (Intervening).

\section{FINDINGS AND DISCUSSION}

\section{Convergent Validity}

Convergent Validity testing of each construct indicator. According to Chin in Ghozali (2014), an indicator is said to be valid if the value is greater than 0.70, while the loading factor of $0.50-0.60$ can be considered sufficient. Based on these criteria, if there is a loading factor below 0.60 it will drop from the model.

All indicators have met the convergent validity because they have a loading factor value $>0.5$, meaning that all indicators are declared valid and can be accepted as latent variable indicators of Product Quality (X1), Service (X2), Price (X3), Brand Image (Y) and Interests buy (Z). Apart from being seen from the loading factor value, convergent validity can also be seen from the Average Variance Extracted (AVE) value. AVE values for all variables are at values above 0.50. The lowest value of AVE is 0.505 in the construct of product quality.

\section{Discriminant Validity}

To analyze whether the research model has good Discriminant Validity, there are two steps that must be done, namely the results of cross loading and the results of the fornell larcker criterian (JFJ Hair et al., 2014; Henseler, Ringle, CM, \& Sinkovics, 2009). The results showed that the cross loading value of each item on its construct was greater than the loading value with other constructs. From these results it can be concluded that there is no problem with discriminant validity. All indicators have a correlation coefficient that is greater with 
each construct than the indicator correlation coefficient value in the construct block in the other columns.

The product quality construct correlations ranged from 0.633 to 0.778 . In terms of service quality, the correlation of service quality constructs ranges from 0.696 to 0.795 . In terms of price, the price construct correlation ranges from 0.791 to 0.829 . In the brand image, the correlation of the brand image construct ranges from 0.733 to 0.827 . In purchase interest, the correlation of the purchase interest construct ranges from 0.725 to 0.811 .

\begin{tabular}{|c|c|c|c|c|c|}
\hline Variable & $\begin{array}{l}\text { Brand } \\
\text { Image }\end{array}$ & Price & $\begin{array}{l}\text { Service } \\
\text { Quality }\end{array}$ & $\begin{array}{l}\text { Product } \\
\text { Quality }\end{array}$ & $\begin{array}{c}\text { Purchase } \\
\text { interest }\end{array}$ \\
\hline Brand Image & $\mathbf{0 , 7 8 9}$ & & & & \\
\hline Price & 0,775 & 0,806 & & & \\
\hline Service & 0,744 & 0,740 & 0,748 & & \\
\hline Quality & & & & & \\
\hline $\begin{array}{l}\text { Product } \\
\text { Quality }\end{array}$ & 0,704 & 0,708 & 0,701 & 0,710 & \\
\hline $\begin{array}{l}\text { Purchase } \\
\text { interest }\end{array}$ & 0,754 & 0,739 & 0,742 & 0,705 & 0,766 \\
\hline
\end{tabular}

Source: Processed Data With SmartPLS 2020 Version 3.3.2

From table 1 it can be seen that $\sqrt{ } A V E$ value of the price correlation variable is 0.806 . This value is greater than the correlation value of the price variable with brand image and other variables. It also applies to other variables, the value of $\sqrt{ } A V E$ in the variable itself shows a greater number than the correlation between variables. Thus the conditions for Discriminant Validity with $\sqrt{ } A V E$ are fulfilled.

\section{Reliability Test}

Composite reliability testing aims to test the reliability of the instrument in a research model. Reliability testing uses two parameters (Hair et al., 2017) : Cronbach's alpha and Composite reliability $>0.70$. The construct is said to have high reliability if the value is 0.70 . The table of Composite Reliability values is as follows:

Table 2 Test Results for Composite Reliability and Cronbach's Alpha
\begin{tabular}{|l|l|l|l|}
\hline \multicolumn{1}{|c|}{ Variable } & $\begin{array}{c}\text { Cronbach's } \\
\text { Alpha }\end{array}$ & $\begin{array}{l}\text { Composite } \\
\text { Reliability }\end{array}$ & Information \\
\hline Brand Image & 0.913 & 0.930 & Reliable \\
\hline Price & 0.908 & 0.927 & Reliable \\
\hline Service Quality & 0.920 & 0.933 & Reliable \\
\hline Product Quality & 0.902 & 0.918 & Reliable \\
\hline Purchase interest & 0.859 & 0.895 & Reliable \\
\hline
\end{tabular}

Source : Processed Data With SmartPLS 2020 Version 3.3.2

Based on the table above, it can be concluded that all reliable constructs, both composite reliability and Cronbach's alpha, have a value above 0.70 . Thus, all variables in this research model have internal consistency reliability. Based on some of the previous data, it can be concluded that this study has good convergent validity, good discriminant validity, and good internal consistency reliability. 


\section{R-Square Value}

Table 3 Test Results of R-Square $\left(\mathbf{R}^{2}\right)$ Value

\begin{tabular}{ll}
\hline Variable & R-Square $\left(\mathbf{R}^{\mathbf{2}}\right)$ \\
\hline Brand Image & 0.730 \\
Purchase interest & 0.831 \\
\hline
\end{tabular}

Source: Data processed by SmartPLS 2020 Version 3.3.2

From the table $\left(\mathrm{R}^{2}\right)$ above gives:

1. Value of 0.730 for the brand image variable (Y) which means that the variable ability of product quality, service, price in explaining the brand image is $73.0 \%$ and the remaining $27.0 \%$ is not explained in this study.

2. The value of 0.831 for the Purchase Interest variable $(Z)$ which means that the ability of the variable Product Quality, Service, Price in explaining Purchase Intention is $83.1 \%$ and the remaining $16.9 \%$ is not explained in this study.

\section{Goodness of Fit Model}

Testing the Goodness of Fit structural model on the inner model uses the predictive relevance value $\left(Q^{2}\right)$. Q-Square value greater than 0 (zero) indicates that the model has a predictive relevance value. The R-Square value of each endogenous variable in this study can be seen in the following calculations:

$$
\begin{aligned}
& Q^{2}=1-\left(1-R_{1}{ }^{2}\right) \times 1-\left(1-R_{2}{ }^{2}\right) \\
& Q^{2}=1-(1-0.730) \times 1-(1-0,831) \\
& Q^{2}=1-(0,247) \times(0,169) \\
& Q^{2}=1-(0,0417) \\
& Q^{2}=0,96
\end{aligned}
$$

The results of the above calculations show the predictive relevance value of 0.96 . This shows the great diversity of research data that can be explained by the research model is $96 \%$. While the remaining $4 \%$ is explained by other factors that are outside of this research model. Thus, from these results, this research model can be stated as having a good goodness of fit.

\section{Hypothesis test}

Hypothesis testing is carried out based on the results of the Inner Model (structural model) test which includes the r-square output, parameter coefficient and t-statistic. To see whether a hypothesis can be accepted or rejected, among others, by paying attention to the significance value between the constructs, t-statistics, and p-values. This research hypothesis testing was carried out with the help of SmartPLS (Partial Least Square) software version 3.3.2. These values can be seen from the bootstrapping results. The rules of thumb used in this study are t-statistic> 1.96 with a significance level of p-value $0.05(5 \%)$ and the path coefficient is positive.

Table 4 Estimation Results of Path Coefficients

\begin{tabular}{|l|l|l|l|}
\hline \multicolumn{1}{|c|}{ Hypothesis } & $\begin{array}{c}\text { Path Value } \\
\text { Coefficients }\end{array}$ & $\begin{array}{c}\text { T Statistics } \\
(\mid \mathbf{O} / \text { STDEV })\end{array}$ & $\begin{array}{c}\text { P } \\
\text { Values }\end{array}$ \\
\hline Product Quality -> Brand Image & 0.326 & 3.367 & 0.001 \\
\hline Service Quality -> Brand Image & 0.313 & 3.314 & 0.001 \\
\hline Price -> Brand Image & 0.252 & 2.704 & 0.007 \\
\hline
\end{tabular}




\begin{tabular}{|l|l|l|l|}
\hline $\begin{array}{l}\text { Product Quality -> Purchase } \\
\text { interest }\end{array}$ & 0.065 & 0.836 & 0.404 \\
\hline Service Quality -> Purchase interest & 0.073 & 0.751 & 0.453 \\
\hline Price -> Purchase interest & 0.612 & 9.078 & 0.000 \\
\hline Brand Image -> Purchase interest & 0.206 & 2.811 & 0.005 \\
\hline
\end{tabular}

Source: Data processed by Smart PLS 2020 Version 3.3.2

Based on the results of the PLS (Partial Least Square) analysis above shown in Table 4 , this section can explain the proof of the hypothesis that has been set. This hypothesis includes proof of how the influence of product quality, service, price on brand image and its impact on purchase intention and the role of brand image in mediating the three independent variables on purchase intention. How the influence of each variable on other variables can be explained in each discussion of the test that can be hypothesized as follows:

1. Product quality is proven to have a positive and significant effect on brand image

2. Service Quality is proven to have a positive and significant influence on Brand Image

3. Price is proven to have a positive and significant effect on Brand Image

4. Product quality is proven to have a positive and insignificant effect on Purchase Intention

5. The effect of service quality on purchase intention is positive but not significant

6. Price is proven to have a positive and significant effect on Purchase interest

7. The influence of brand image on purchase intention is significant positive

The next step is to estimate the indirect effect simultaneously by adding a mediating variable between the independent and dependent variables. The author estimates the indirect effect, namely the role of the brand image variable in mediating the influence of the variable product quality, service, and price on purchase intention. The results of the indirect effect estimation are presented in the following table form:

Table 5 Estimation Results of the Indirect Effect Path Coefficient

\begin{tabular}{|l|c|c|c|}
\hline \multicolumn{1}{|c|}{ Hypothesis } & $\begin{array}{c}\text { Path } \\
\text { Coefficients }\end{array}$ & P Values & Information \\
\hline $\begin{array}{l}\text { Product Quality -> Brand } \\
\text { Image -> Purchase interest }\end{array}$ & 0.067 & 0.042 & Significant \\
\hline $\begin{array}{l}\text { Service Quality -> Brand Image } \\
\text {-> Purchase interest }\end{array}$ & 0.064 & 0.053 & Not significant \\
\hline $\begin{array}{l}\text { Price -> Brand Image -> } \\
\text { Purchase interest }\end{array}$ & 0.052 & 0.045 & Significant \\
\hline
\end{tabular}

Source: Data processed by SmartPLS 2020 Version 3.3.2

The results from table 5 will be explained below:

1. Brand image mediates the relationship between product quality and purchase intention

2. Brand image does not mediate the relationship between service quality and purchase intention

3. Brand image mediates the relationship between price and purchase intention

\section{CONCLUSION AND SUGGESTION}

The conclusions in this study will be explained as follows: Product quality has a positive and significant effect on Brand Image, which means that the higher the quality of Daihatsu Xenia products, the brand image will increase, conversely, if consumers do not get good product quality, the brand image owned by Daihatsu Xenia products will decrease. These results are supported by the results of the analysis of the product quality variable 
descriptions which indicate that the salient aspect of the research results is the design aspect. In general, consumers have evaluated the quality of the product as good. This is indicated by $\geq 70 \%$ of consumers agreeing / strongly agreeing on the dominance of the design aspect, namely for the Daihatsu Xenia Car Design question following trends, starting from color, shape and size. Then also the performance aspect, namely the question of the fuel efficient Daihatsu Xenia.

Service Quality has a positive and significant effect on Brand Image, which means that the better the service quality of a company, the more its brand image will be. This result is supported by the analysis of the description of the service quality variable which shows that $\geq 70 \%$ of consumers agree / strongly agree on the aspects of assurance and reliability, namely for questions Daihatsu employees have friendliness in communicating and Daihatsu staff show the accuracy of providing information to consumers. Another $32.1 \%$ of consumers still have doubts, the quality of service that is felt to be inadequate or not in accordance with the expectations of consumers for the services provided is shown from the dimension of empathy, namely the sensitivity of Daihatsu employees in understanding the desires of consumers.

Price has a positive and significant effect on Brand Image. This result is supported by the results of the analysis of the price variable description where the most prominent aspect of the results of this study is the aspect of price suitability with benefits, which shows that $\geq 70 \%$ of consumers feel the price of the Daihatsu Xenia car is in accordance with the benefits. On the other hand, $\geq 26$ percent of consumers are still in doubt about the suitability of the Daihatsu Xenia car price with the product being offered.

Another conclusion is that product quality has a positive and insignificant effect on consumer purchase interest. Service quality has a positive and insignificant effect on consumer purchase interest. Price has a positive and significant effect on consumer purchase interest. Brand image has a positive and significant effect on purchase intention. This result is supported by the results of the analysis of the description of service quality variables where the most prominent aspect of the results of this study is the aspect of the image of the maker which shows that $\geq 70 \%$ of consumers agree / strongly agree that the brand logo is easy to recognize. On the other hand, $28.4 \%$ of consumers still have doubts about the dimensions of the user's image, whether Daihatsu is a brand that reflects high social status.

The results of the study indicate that brand image is proven to be able to fully mediate product quality on consumer purchase interest, in other words, brand image strengthens the effect of product quality from previously not having a significant effect on purchase intention after the existence of a brand image as a mediation of the effect of product quality on increased purchase intention. . Then the brand image is not proven to mediate the quality of service on consumer purchase interest and also the brand image is proven to partially mediate the price on consumer purchase interest.

Based on the discussion and conclusions that have been obtained in this study, the authors propose several suggestions as follows:

From the results of hypothesis testing that product quality affects purchase intention mediated by brand image. In this case the researchers suggest that companies be able to improve and maintain the design aspects, namely the Daihatsu Xenia car design following trends, ranging from color, shape and size, this aspect is very prominent from the results of this study, and in general consumers have assessed the quality of the product. In addition, Daihatsu also needs 
to pay attention to aspects of reliability and performance because from the analysis of the descriptions, most respondents still think that they have not met expectations.

In line with the results of hypothesis testing that price is the most significant variable affecting purchase intention. In this case, the researcher suggests the company to be able to maintain and improve consumer perceptions of the price offered, especially aspects of price compatibility with product benefits. In addition, to increase the perception of price, Daihatsu Xenia also needs to pay attention to the aspect of price compatibility with quality, because most respondents still think that they have not met expectations, feel that the price of the Daihatsu Xenia car does not match the product being offered.

From the results of hypothesis testing that brand image has a positive and significant effect on purchase intention. In this case the researcher suggests the company to be able to maintain and improve aspects of the image of the maker and the image of the product. On the other hand, $28.4 \%$ of respondents still doubt whether Daihatsu is a brand that reflects high social status. and respondents who agreed / strongly disagreed with the dimensions of the user image reached 69\%. Therefore Daihatsu must be able to increase respondents' perceptions of user image. because most respondents still think that they have not met expectations.

The results of this study can be used as a reference material that can be used as a reference for further research with the same focus of study by involving a wider group of respondents so that it can provide more comprehensive results regarding the interest in buying LMPV cars for Indonesian consumers.

From the research results, service quality does not have a significant effect. It is hoped that further research will be able to further dissect what factors are related to service quality that can affect the interest in buying a Daihatsu Xenia car.

In addition, it is expected to add other variables that can mediate the effect of service quality on purchase intention besides brand image, then dissect other factors that exist in the price because in the research results it is found that the brand image partially mediates price on purchase intention.

In order to increase consumer purchase interest based on the brand image of Daihatsu Xenia cars, the company should always maintain and continue to improve the current brand image, especially with regard to performance, in this study the indicator that has the lowest loading factor value Daihatsu Xenia has a soft suspension system so that comfortable when driving, the company should try to develop technology application of active suspension technology in cars.

\section{REFERENCE}

Aaker, David, A. dan Alexander, L. Biel, 2009, Brand Equity and Advertising: Advertising Role In Building Strong Brand, Lawrence Erlbaum Associates. Inc., Hillsdale.

A. Parasuraman, Valarie A. Zeithaml, and Leonard L. Berry. 1988. "SERVQUAL: A Multiple-Item Scale for Measuring Consumer Perceptions of Service Quality”. Journal of Retailing. Vol 64 (1) pp 12- 37.

Agung Ratih Saraswati dan Ketut Rahyuda 2017 Brand Image Memediasi Kualitas Produk Dan Harga Dengan Keputusan Pembelian Smartphone Apple Di Kota Denpasar EJurnal Manajemen Unud, Vol. 6, No. 6,ISSN : 2302-8912. 
Augusty, Ferdinand. (2013). Metode Penelitian Manajemen. Semarang. Badan Penerbit Universitas Diponegoro.

Hair, Joseph F. Jr. et al. 2010. Multivariate Data Analysis $7^{\text {th }}$ Edition. Pearson Education Limited. Harlow. England.

Hair, Joseph F. Jr. et al. 2014. A Primer On Partial Least Squares Structural Equation Modelling $\{P L S-S E M\}$. SAGE Publications, Inc. California. USA.

Hair, J. F., Hult, G. T. M., Ringle, C., \& Sarstedt, M., 2017. A Primer on Partial Least Squares Structural Equation Modeling (PLS-SEM) second ed. London, Thousand Oaks, Calif : Sage Publications Limited Inc Hanseler, J., \& Sarstedt, M. 2012. Goodness-of-fit i

Kotler, Philip; Armstrong, Garry, 2008. Prinsip-prinsip Pemasaran,Jilid 1, Erlangga, Jakarta.

Kotler, P. \& Keller, (2012). Marketing Management, 14th Global Edition, Prentice Hall International, Inc., USA.

Kotler Philip, Amstrong Gary. 2013. Prinsip-prinsip Pemasaran, Edisi ke-12. Penerbit Erlangga.

Kotler, Philip dan Amstrong, Gary, (2014), Principles of Marketing, 12th Edition, Jilid 1 Terjemahan Bob Sabran Jakarta : Erlangga.

Kotler, Philip and Kevin Lane Keller, (2016): Marketing Management, 15th Edition New Jersey: Pearson Pretice Hall, Inc.

Maunaza, A. (2012) Pengaruh Brand Image Terhadap Minat Beli Konsumen. Universitas Diponegoro

Mohamad Yusuf Farhan, Mustafa Kamal N (2015) analisis pengaruh citra merek, desain produk, dan kualitas produk terhadap keputusan pembelian sepatu nike (studi kasus pada konsumen nike di kota semarang), Diponegoro Journal of Management, Vol 4 Nomor 4.

Rusydi. (2017). Customer Excellence, Yogyakarta: Gosyen Publishing

Schiffman, 1.G. dan Kanuk, Leslie L. 2013. Consumer Behavior. 8th edition. New Jersey: Prentice Hall Inc. New Jersey

Stanton, William J. 2013. Prinsip Pemasaran. Alih Bahasa oleh Buchari Alma. Jilid Satu. Edisi Kesepuluh. Jakarta : Erlangga. 